Original Research

\title{
Effects of Hypersalinity on Serum Nonspecific Immune Indices in Three Marine Organisms
}

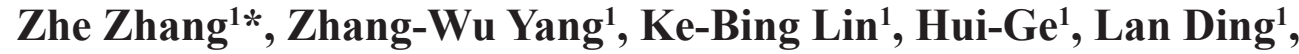 \\ Ya-You Zheng ${ }^{1}$, Gen Zhang ${ }^{2 * *}$
}

${ }^{1}$ Key Laboratory of Cultivation and High-Value Utilization of Marine Organisms in Fujian Province, Fisheries Research Institute of Fujian, Xiamen, P. R. China

${ }^{2}$ Shenzhen GenProMetab Biotechnology Company Limited, Shenzhen, R. R. China

Received: 16 May 2019

Accepted: 2 July 2019

\begin{abstract}
During the production of desalination plants, concentrated seawater is expelled to local marine environments, which may lead to hypersaline pollution. To assess environmental risk of hypersalinity, Crassostrea angulate, Scylla paramamosain and Epinephelus akaara were exposed to salinities of $30 \%$, 36\% and 40\%, then changes of serum nonspecific immune indices were monitored for 96 hours, including superoxide dismutase (SOD) and acid phosphatase (ACP) activity, and contents of serum total protein and albumin. Two-way ANONA revealed that salinity only affected contents of serum total protein and albumin in C. angulate, and content of serum albumin in $S$. paramamosain and content of serum total protein in E. akaara. Compared with the control, hypersaline treatments (36\%o and/or 40\%) first increased contents of serum total protein and albumin and then decreased them in C. angulate, suppressed content of serum albumin in S. paramamosain, and increased content of serum total protein in E. akaara. These results suggested that exposure to hypersalinity might enhance innate immunity of C. angulate and E. akaara, but suppressed it in S. paramamosain.
\end{abstract}

Keywords: saline stress, superoxide dismutase, acid phosphatase, serum total protein, albumin

\section{Introduction}

Desalination is an energy-intensive process. With the development of seawater desalination industries, a huge amount of hypersaline wastewater is produced. At present, the comprehensive utilization of hypersaline wastewater mainly focuses on extraction of potassium, magnesium and bromide. However, a considerable ratio

*e-mail: 359340028@qq.com

**e-mail: zhanggen1988@163.com of concentrated seawater is still discharged to local seas directly, therefore raising ecological concerns to local marine environments [1].

Salinity can affect the physiological process of marine organisms such as enzymatic activity, reproduction, growth, breathing and behavior [2] by altering osmoregulation, protein synthesis, oxygen uptake, and extracellular acid-base balance [3]. Ecological investigations on areas close to desalination plants have revealed that discharge of concentrated seawater formed hypersaline areas that significantly destructed habitats; decreased densities of fish, echinoderms and planktons; inhibited shoot division of 
Posidonia oceanica; and negatively affected the growth of corals $[4,5]$. These results preliminarily demonstrated negative influences of desalinization plants.

Innate immunity (nonspecific immunity) provides rapid and incomplete antimicrobial host defense before the development of slower, more definitive acquired specific immune responses, which needs several weeks to synthesize antibodies. Obviously, innate immunity contributes important roles to animal health. Up to data, the effects of hypersalinity on marine animals are still largely unknown. Compared with $28.5 \%$ salinity, Dicentrarchus labrax at 35\% revealed higher levels of nephrosin in intestine, which represented the function of the immune system [6]. Matozzo et al. reported a decrease in the phagocytic index of the immune system cells in the clams Chamelea gallina exposed to hypersalinity (40\%) [7]. A similar decrease was also observed in Macrocallista nimbosa [8]. However, several reports also indicated that increased salinity did not significantly affect immune parameters in Mytilus coruscu and Oreochromis niloticus [9, 10]. These conflicted results suggested that the effects of hypersalinity on nonspecific immunity might differ among species. Investigations on more species are required.

Crassostrea angulata, Scylla paramamosain and Epinephelus akaara are three typical and ordinary species living in coastal marine habitats. They are possibly affected by hypersaline seawater released from desalinization plants. SOD activity is closely associated with immune function in marine organisms $[11,12]$. Acid phosphatase (ACP) is also a typical lysosome enzyme that plays a role in killing and digesting pathogens [13]. Serum total protein and serum albumin maintain the $\mathrm{pH}$ balance in the blood and the stability of the physiological environment, and function as an important endogenous antioxidant in plasma [14-16]. These indices are considered as indices of nonspecific immunity [17]. In the present study, to investigate the effects of hypersaline seawater on C. angulata, S. paramamosain and E. akaara, changes of SOD and ACP activities as well as contents of serum total protein and albumin were compared among treatments with $30 \%$, 36\%o and $40 \%$. These results might contribute to comprehensive assessment of environmental risk of desalination plants to local marine environments.

\section{Materials and Methods}

\section{Hypersaline Treatment}

C. angulata (weight: $98.6 \pm 21.7$ g), E. akaara (weight: $135.9 \pm 20.6 \mathrm{~g}$ ) and $S$. paramamosain (weight: $251.9 \pm 79.1 \mathrm{~g}$, length: $10.26 \pm 0.85 \mathrm{~cm}$ ) were purchased from a commercial aquafarm located as Haicang District, Xiamen City, Fujian Province, P. R. China.
Animals were maintained at $30 \%$ salinity for two days in order to observe their healthy status. Seawater was prepared by dissolving artificial sea salts in distilled water.

The general salinity at the sampling location was $30 \%$ and salinity of seawater near the local desalination plant was up to $40 \%$. In order to investigate the effects of hypersalinity on experimental animals, salinities of $36 \%$ and $40 \%$ were set as hypersaline treatments and $30 \%$ was included as control. Animals were randomly distributed into these three groups. Experiments were conducted in $50 \mathrm{~L}$ glass tanks. Each treatment included three tanks as three replicates.

After being treated for $0,2,6,12,24,48$ and $96 \mathrm{~h}$, three individuals of each species were sampled from each treatment. Animals were sacrificed on ice. Blood was collected and stored at $4^{\circ} \mathrm{C}$ overnight. After centrifugation at $5,000 \mathrm{rpm}$ and $4^{\circ} \mathrm{C}$ for $5 \mathrm{~min}$, serum was collected for determining SOD and ACP activities as well as contents of serum total protein and albumin.

\section{Determining SOD and ACP Activities}

Activities of SOD and ACP were determined using commercial kits produced by Nanjing Jiancheng Biotechnology Company (Nanjing, China). Following the kits' protocols, SOD activity was assayed using the xanthine/xanthine oxidase method based on the production of $\mathrm{O}_{2}^{-}$, and ACP activity was measured using disodium phenyl phosphate as the substrate. One unit of SOD activity was defined as the amount of enzyme required for $1 \mathrm{mg}$ tissue proteins in $1 \mathrm{ml}$ of reaction mixture to achieve an SOD inhibition rate of $50 \%$. One unit of ACP was expressed as the degradation of $1 \mathrm{mg}$ of phenol at $37^{\circ} \mathrm{C}$ in $60 \mathrm{~min}$.

\section{Determining the Contents of Serum Total Protein and Albumin}

A protein determination kit and albumin determination kit were purchased from Nanjing Jiancheng Biotechnology Company (Nanjing, China). The assays were carried out exactly following the kits' protocols. Determination of total protein and albumin employed the Coomassie brilliant blue G250 method and Bromocresol green colorimetric method, respectively.

\section{Data Analyses}

SPSS 18.0 software was used for statistical analyses. Two-way analysis of variance (ANOVA) was applied to check the effects of salinity, time and their iteration on each parameter. One-way ANOVA was applied to evaluate the effects of salinity on all parameters at the same time point, followed by multiple comparisons (SNK test). Differences were considered significant at $P<0.05$. All data are expressed as mean \pm standard deviation (SD). 


\section{Results}

\section{Effects of Hypersalinity on C. angulata}

Along with exposure time, at salinity of $36 \%$ SOD activity decreased from $2 \mathrm{~h}$ and then increased from 24 $\mathrm{h}$ to the maximum value at $48 \mathrm{~h}$. A similar trend was observed in treatment with $40 \%$ (Fig. 1a). Compared with the control, SOD activity was significantly reduced in treatments with $36 \%$ and $40 \%$ within $12 \mathrm{~h}$, but increased in treatment with $36 \%$ from $24 \mathrm{~h}$ to $96 \mathrm{~h}$ and in treatment with $40 \%$ at $48 \mathrm{~h}$ (Fig. 1a).

Compared with the control, ACP activity was significantly elevated in treatment with $36 \%$ at $2 \mathrm{~h}, 24$ $\mathrm{h}$ and in treatment with $40 \%$ at $96 \mathrm{~h}$, but significantly decreased in treatment with $40 \%$ at $48 \mathrm{~h}$ (Fig. 1b).

Compared with the control, the content of serum total protein increased in treatment with $40 \%$ at $2 \mathrm{~h}$, but was significantly lower in treatments with $36 \%$ and $40 \%$ at $6 \mathrm{~h}$ and $48 \mathrm{~h}$ (Fig. 1c).

During the initial exposure period (from $2 \mathrm{~h}$ to $24 \mathrm{~h}$ ), content of serum albumin was significantly higher in treatments with $36 \%$ and $40 \%$ o than that in $30 \%$. Along with exposure time, the content of serum albumin revealed decreasing trends from $2 \mathrm{~h}$ to $48 \mathrm{~h}$ at salinities of 36\% and 40\%o (Fig. 1d).

\section{Effects of Hypersalinity on S. paramamosain}

Compared with the control, SOD activity at salinity of $36 \%$ showed no significant change during the experiment. However, at salinity of $40 \%$, it significantly increased at $2 \mathrm{~h}$ but decreased at $48 \mathrm{~h}$ and $96 \mathrm{~h}$ (Fig. 2a).

At $2 \mathrm{~h}$ and $12 \mathrm{~h}, \mathrm{ACP}$ activity in the 36\% group was significantly lower than those in control. In the 40\% group it was significantly higher than that in control at $12 \mathrm{~h}$ (Fig. 2b).

Content of total serum protein in the $36 \%$ group significantly decreased at $2 \mathrm{~h}$, but significantly increased at $96 \mathrm{~h}$ compared with control. Serum total protein content in the $40 \%$ group increased significantly $(2 \mathrm{~h}-48 \mathrm{~h})$ compared with control, with a maximum value at $6 \mathrm{~h}$ (Fig. 2c).

Compared with the control, serum albumin content in the 36\% group significantly decreased at $2 \mathrm{~h}, 6 \mathrm{~h}$ and $12 \mathrm{~h}$, with those in the $40 \%$ group significantly lower at $2 \mathrm{~h}$ and $24 \mathrm{~h}$ (Fig. 2d).
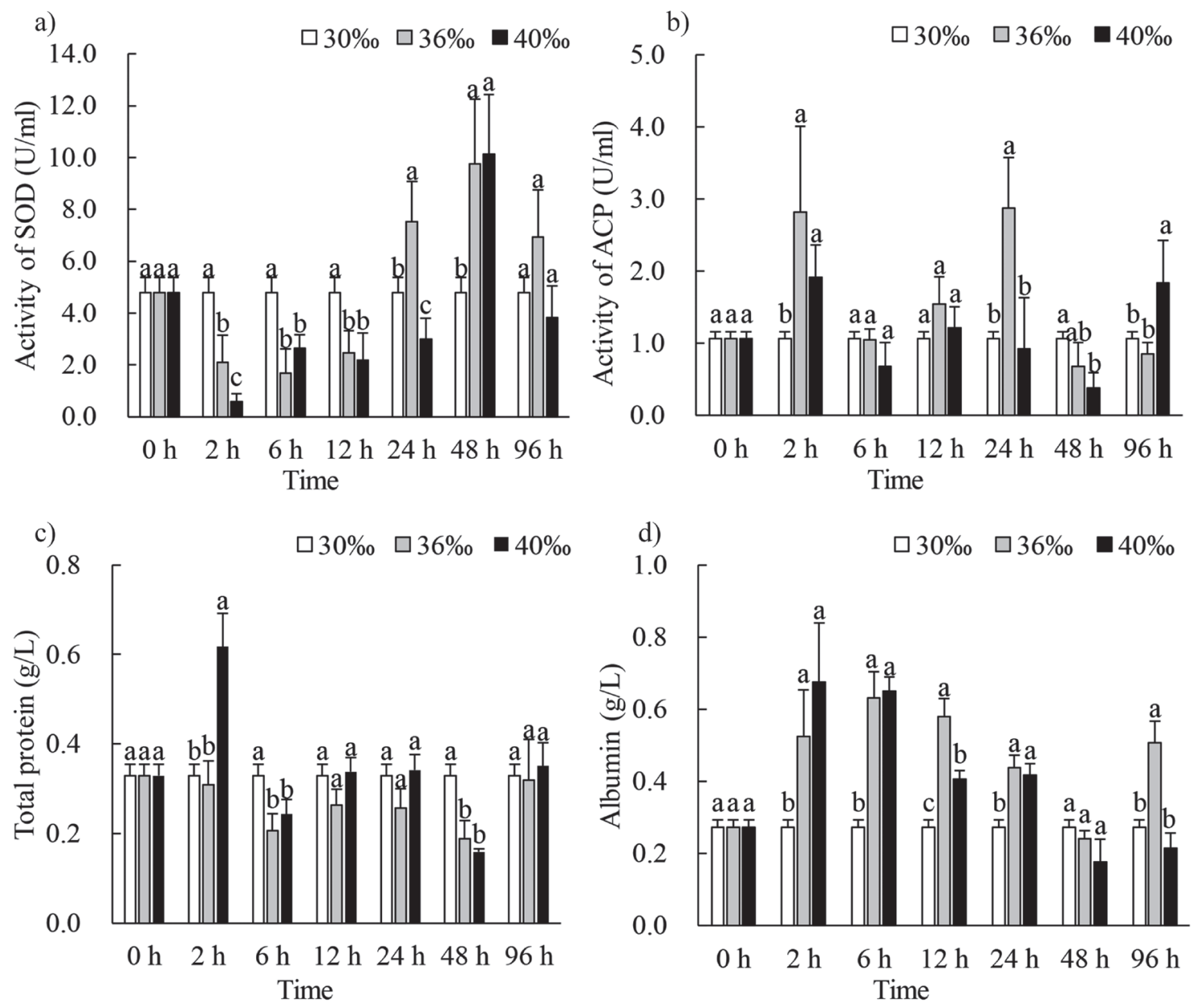

Fig. 1. Effects of hypersalinity on serum nonspecific immune indices in Crassostrea angulate; data represent mean $\pm \mathrm{SD}$; different letters indicate significant differences among salinities in the same time slot $(P<0.05)$. 

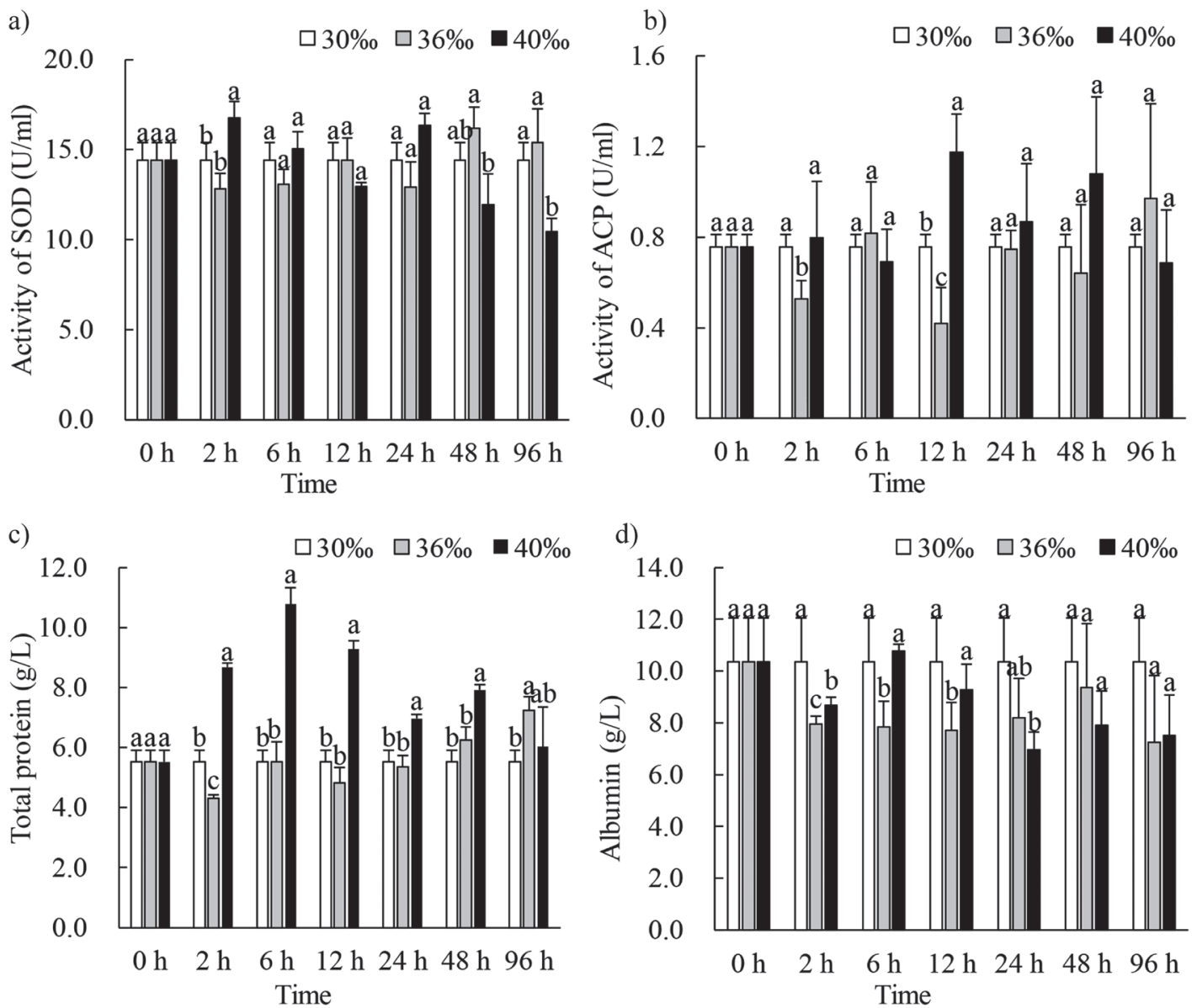

Fig. 2. Effects of hypersaline stress on serum nonspecific immune indices in Scylla paramamosain; Data represent mean $\pm \mathrm{SD}$; different letters indicate significant differences among salinities in the same time slot $(P<0.05)$.

\section{Effects of Hypersalinity on E. akaara}

Compared with the control group, SOD activity significantly increased at $48 \mathrm{~h}$ and $96 \mathrm{~h}$ in treatments with $36 \%$ and $40 \%$. No significant difference was detected among three saline treatments from $0 \mathrm{~h}$ to $24 \mathrm{~h}$ (Fig. 3a).

ACP activity significantly decreased in treatment with $36 \%$ at $2 \mathrm{~h}, 12 \mathrm{~h}$ and $48 \mathrm{~h}$, as well as in treatment with $40 \%$ at $2 \mathrm{~h}$ and $48 \mathrm{~h}$, compared with the control. An increased level of ACP activity was detected in treatment with $40 \%$ at $6 \mathrm{~h}$ than that at $30 \%$ (Fig. 3b).

Content of total serum protein at salinities of $36 \%$ and $40 \%$ significantly increased from $2 \mathrm{~h}$ to $24 \mathrm{~h}$, compared with control group (Fig. 3c).

Salinity and exposure time did not significantly affect the content of serum albumin in the present experiments (Fig. 3d).

\section{Discussion}

Salinity is a key environmental factor to determine the growth and health of marine organisms. Each marine species adapts to an optimal salinity and can tolerate temporary or slight variation of salinity. However, exposure to large saline differences for a long time negatively affects growth of animals and even induces mortality. Previous studies have assessed impacts of brine discharges from desalination plants on marine ecosystems and particularly on marine fauna [1820]. However, the tested indices in these studies were limited to survival, growth, and ecological changes. Toxicological impacts on innate immune responses were poorly investigated [21].

As we know, stress leads to a series of biochemical, physiological and behavioral changes in marine organisms, thus affecting normal body homeostasis. Activities of antioxidant enzymes and the levels of ROS have been found to correlate with various stress [22]. ROS generation is an essential mechanism during phagocytosis [23]. Besides, ROS level is a common feature representing oxidative stress in animals exposed to abiotic stress. Treatments with hypersalinity generally induce production of reactive oxygen species (ROS) in aquatic animals [23, 24], which are harmful to protein, lipid, DNA molecules, and finally damage cytomembrane, enzyme activity and cell function. To resist ROS, organisms may initiate a series of antioxidant reactions $[25,26]$. Among them, SOD is 

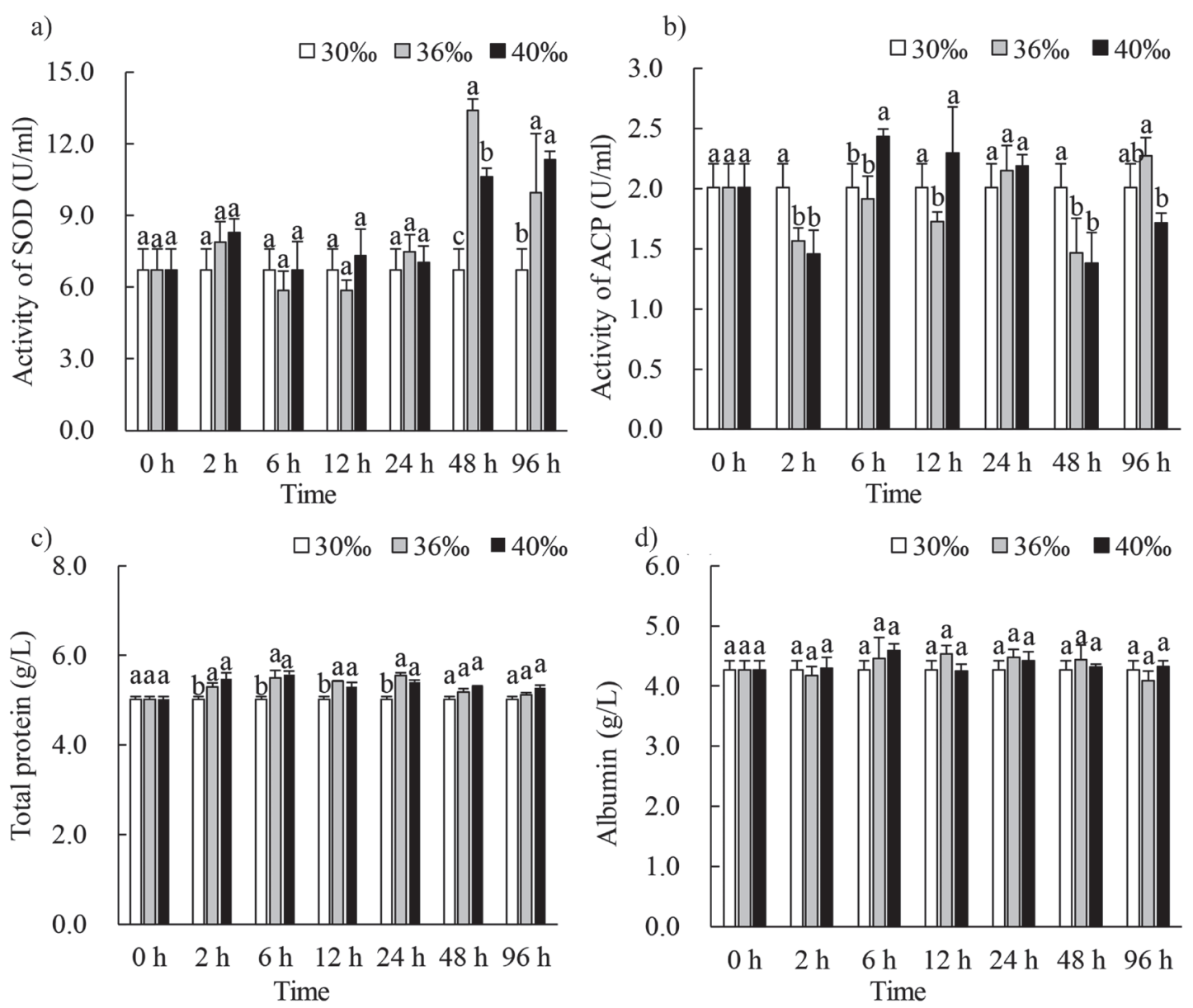

Fig. 3. Effects of hypersaline stress on serum nonspecific immune indices in Epinephelus akaara; data represent mean $\pm \mathrm{SD}$; different letters indicate significant differences among salinities in the same time slot $(P<0.05)$.

a typical enzyme that catalyzes the dismutation (or partitioning) of the superoxide $\left(\mathrm{O}_{2}^{-}\right)$radical into either ordinary molecular oxygen $\left(\mathrm{O}_{2}\right)$ or hydrogen peroxide $\left(\mathrm{H}_{2} \mathrm{O}_{2}\right)$. In the present study, changes of SOD activity varied among species and exposure time. Hypersaline treatments elevated SOD activity in $C$. angulate and $E$. akaara but decreased in S. paramamosain at $48 \mathrm{~h}$ and $96 \mathrm{~h}$, suggesting that phagocytes were more activated in C. angulate and E. akaara, but less activated in $S$. paramamosain in response to hypersalinity. Nonnegligibly, changes of SOD might also be attributed to oxidative stress induced by saline variation [27, 28], or comprehensive effects of oxidative stress and innate response. Moreover, decreased SOD activities were observed in some treatments, which was similar to the results detected in Echinometra lucunter in response to hypersaline treatment [23]. The underlying mechanisms required further investigations.

Fang et al. found that ACP activity in the gill and kidney of the juvenile tongue sole (Cynoglossus semilaevis) showed no significant difference between low- and high-salinity treatments [29]. ACP activity was enhanced in Penaeus vannamei at salinity $30-40 \%$, but significantly reduced at higher salinity [17]. Decreased ACP activity represents an impaired ability to degrade bacteria [30]. In the present study, changes in $\mathrm{ACP}$ activity were not consistent among the three tested species. In C. angulate, ACP activity was enhanced at initial exposure to hypersalinity but then decreased, suggesting that hypersalinity might first enhance but then suppress nonspecific immunity. Increased activity of ACP probably resulted from the proliferation of immune cells under hypersalinity [31]. In E. akaara and S. paramamosain, ACP activity decreased or did not change in hypersaline treatment compared with the control, displaying inhibitive effects on nonspecific immunity.

Increases in serum total protein and albumin are thought to be associated with a stronger innate immune response $[32,33]$. In $C$. angulate, content of serum total protein increased at early contact and then decreased or did not change; content of serum albumin always increased or did not change compared with the control. These results at early contact were consistent with changes of ACP activity, suggesting that hypersaline treatment enhanced the immunity of $C$. angulate initially. In $S$. paramamosain, enhanced content of serum total protein and suppressed content of serum albumin were observed in hypersaline treatments. In $E$. akaara, content of serum total protein was always higher 
Table 1. Two-way analyses of variance - SS: sum of squares; df: degree of freedom; MS: mean square; NA: not applicable .

\begin{tabular}{|c|c|c|c|c|c|}
\hline Sources & SS & df & MS & F & $\mathrm{P}$ \\
\hline \multicolumn{6}{|c|}{ Serum albumin in C. angulate } \\
\hline Time & 0.208 & 6 & 0.035 & 2.514 & 0.082 \\
\hline Salinity & 0.125 & 2 & 0.062 & 4.519 & 0.034 \\
\hline Time * Salinity & 0.165 & 12 & 0.014 & NA & $\mathrm{NA}$ \\
\hline \multicolumn{6}{|c|}{ Serum total protein in S. paramamosain } \\
\hline Time & 5.486 & 6 & 0.914 & 0.527 & 0.778 \\
\hline Salinity & 25.432 & 2 & 12.716 & 7.33 & 0.008 \\
\hline Time $\times$ Salinity & 20.816 & 12 & 1.735 & NA & NA \\
\hline \multicolumn{6}{|c|}{ Serum albumin in S. paramamosain } \\
\hline Time & 8.287 & 6 & 1.381 & 1.48 & 0.265 \\
\hline Salinity & 15.274 & 2 & 7.637 & 8.185 & 0.006 \\
\hline Time $\times$ Salinity & 11.196 & 12 & 0.933 & NA & NA \\
\hline \multicolumn{6}{|c|}{ Serum total protein in E. akaara } \\
\hline Time & 0.251 & 6 & 0.042 & 2.81 & 0.06 \\
\hline Salinity & 0.414 & 2 & 0.207 & 13.902 & 0.001 \\
\hline Time $\times$ Salinity & 0.179 & 12 & 0.015 & NA & NA \\
\hline
\end{tabular}

in hypersaline treatment, but content of serum albumin never changed during the tested period. These results were inconsistent with ACP activity. Based on these data, it was hard to conclude the effects of hypersalinity on nonspecific immune function in $S$. paramamosain and E. akaara. Actually, the nonspecific immune system involves lot of complex molecular mechanisms.

To get more valuable information, two-way ANONA was conducted on all tested parameters in the three species. The results showed that salinity only affected contents of serum total protein and albumin in $C$. angulate, content of serum albumin in $S$. paramamosain and content of serum total protein in E. akaara. No significant effects of time and time $\times$ salinity were detected on all tested indices (Table 1). Based on the changes of the indices significantly revealed by two-way ANOVA, we may conclude that hypersaline treatment enhanced innate immunity of C. angulate and E. akaara, but suppressed it in $S$. paramamosain. Different results among species might be due to the different sensitivities of marine organisms to environmental changes. Further studies are required to clarify the inconsistent changes in the present study.

\section{Conclusions}

Overall, in the present study SOD activity was elevated in $C$. angulate and E. akaara but decreased in S. paramamosain at $48 \mathrm{~h}$ and $96 \mathrm{~h}$ in hypersaline water. ACP activity was enhanced at initial exposure to hypersalinity but then decreased in C. angulate, while it decreased or did not change in E. akaara and $S$. paramamosain. Content of serum total protein increased at early stages and then decreased or did not change in $C$. angulate but was always higher in $E$. akaara and $S$. paramamosain in hypersaline treatments. Content of serum albumin always increased or did not change in $C$. angulate, while it was suppressed in $S$. paramamosain, but it never changed in E. akaara during the tested period. Regardless, the widely accepted view is that the environmental impact of seawater desalination on marine environments will not be substantial if appropriate measures are implemented.

\section{Acknowledgements}

This work was supported by the Special Funds for Research on Marine Public Welfare Industry (grant number 201205019-3), Marine Economic Innovation and Development of Demonstration Projects of Xiamen in the $13^{\text {th }}$ Five-Year Plan (grant number 16PFW034SF02) and the Special fund for Marine and Fishery Structural Adjustment of Fujian Province (2017HYJG09).

\section{Author Contributions}

ZZ, ZWY and KBL designed the experiments. HG and DL collected the experiments and analyzed the 
data. DL, YYZ and GZ drafted the manuscript and all authors revised it.

\section{Conflict of Interest}

There is no conflict of interest in this research.

\section{References}

1. XEVGenos D., DIMOPOUlOS K., MOUSTAKAS K., MALAMIS D., LOIZIDOU M. Enhanced resource efficiency in the desalination sector through resource recovery from brine. Governance \& Financing for the Mediterranean Water Sector. Barcelona: 1, 2013.

2. MIRI R., CHOUIKHI A. Ecotoxicological marine impacts from seawater desalination plants. Desalination, 182 (1), 403, 2005.

3. RODRIGUES A.P., OLIVEIRA P.C., GUILHERMINO L., GUIMARÃES L. Effects of salinity stress on neurotransmission, energy metabolism, and anti-oxidant biomarkers of Carcinus maenas from two estuaries of the NW Iberian Peninsula.” Mar. Biol. (Berlin) 159 (9), 2061, 2012.

4. FERNÁNDEZ-TORQUEMADA Y., SÁNCHEZ-LIZASO J.L., GONZÁLEZ-CORREA J.M. Preliminary results of the monitoring of the brine discharge produced by the SWRO desalination plant of Alicante (SE Spain). Desalination, 182 (1), 395, 2005.

5. RAVENTOS N., MACPHERSON E., GARCÍA-RUBIÉS A. Effect of brine discharge from a desalination plant on macrobenthic communities in the NW Mediterranean. Mar. Environ. Res. 62 (1), 1, 2006.

6. BOUTET I., LONG KY C.L., BONHOMME F. A transcriptomic approach of salinity response in the euryhaline teleost, Dicentrarchus labrax. Gene, 379, 40, 2006.

7. MATOZZO V., MONARI M., FOSCHI J., SERRAZANETTI G.P., CATTANI O., MARIN M.G., Effects of salinity on the clam Chamelea gallina haemocytes. Part II: superoxide dismutase response. Mar. Biol. 151 (3), 1059, 2007.

8. JAUZEIN C., DONAGHY L., VOLETY A.K., Flow cytometric characterization of hemocytes of the sunray venus clam Macrocallista nimbosa and influence of salinity variation. Fish Shellfish Immunol. 35 (3), 716, 2013.

9. WU F., XIE Z., LAN Y., DUPONT S., SUN M., GUI S., HUANG X., HUANG W., LIU L., HU M., LU W., WANG Y. ShoRT-TERM EXPosure of Mytilus coruscus to decreased $\mathrm{pH}$ and salinity change impacts immune parameters of their haemocytes. Front. Physiol. 9, 166, 2018.

10. Choi K., Cope W.G., Harms C.A., Law J.M. Rapid decreases in salinity, but not increases, lead to immune dysregulation in Nile tilapia, $\backslash \mathrm{r}$, Oreochromis niloticus $\backslash \mathrm{r}$, (L.). J. Fish Dis. 36 (4), 389, 2013.

11. ANGULO C., MALDONADO M., DELGADO K., REYES-BECERRIL M. Debaryomyces hansenii up regulates superoxide dismutase gene expression and enhances the immune response and survival in pacific red snapper (Lutjanus peru) leukocytes after vibrio parahaemolyticus infection. Dev. Comp. Immunol. 71, 18, 2017.
12. WANG M., WANG B., JIANG K., LIU M., SHI X., WANG L. A mitochondrial manganese superoxide dismutase involved in innate immunity is essential for the survival of Chlamys farreri. Fish Shellfish Immunol. 72, 282, 2018.

13. FEI Y., DAN X.M., SUN P., SHI Z.H., GAO Q.X., PENG S.M., LI A.X. Growth, feed intake and immune responses of orange-spotted grouper (Epinephelus coioides) exposed to low infectious doses of ectoparasite (Cryptocaryon irritans). Fish Shellfish Immunol. 36 (1), 291, 2014.

14. ROHACOVA, J., MARIN M.L., MIRANDA M.A. Complexes between Fluorescent Cholic Acid Derivatives and Human Serum Albumin. A Photophysical Approach To Investigate the Binding Behavior. J. Phys. Chem. B. 114 (13), 4710, 2010.

15. BARAKA-VIDOT J., GUERIN-DUBOURG A., DUBOIS F., PAYET B., BOURDON E., RONDEAU P. New insights into deleterious impacts of in vivo glycation on albumin antioxidant activities. Biochim. Biophys. Acta. 1830 (6), 3532, 2013.

16. BICUDO L.D.C., LOPES R.S., TAKAHIRA R.K., RODELLO L., BICUDO S.D. Monitoring of acquisition of passive immunity in lambs with voluntary colostrum intake by determining the serum total protein. Veterinária E Zootecnia. 22 (3), 437, 2015.

17. LI N., ZHAO Y., WANG R., SHEN M., LI Y. Effects of high salinity on digestive and immunity related enzymes in Litopenaeus vannamei. Acta Ecologica Sinica. 38 (4), 1411, 2018 [In Chinese].

18. RIERA R., TUYA F., SACRAMENTO A., RAMOS E., RODRÍGUEZ M., MONTERROSO Ó. The effects of brine disposal on a subtidal meiofauna community. Estuar. Coast. Shelf Sci. 93 (4), 359, 2011.

19. YOLANDA F.T., GONZÁLEZ-CORREA J.M., SÁNCHEZ-LIZASO J.L. Echinoderms as indicators of brine discharge impacts. Desalin. Water Treat. 51 (1-3), $567,2013$.

20. BELATOUI A., BOUABESSALAM H., HACENE O.R., DE-LA-OSSA-CARRETERO J.A. MARTINEZGARCIA E., SANCHEZ-LIZASO J.L. Environmental effects of brine discharge from two desalination plants in Algeria (South Western Mediterranean). Desal. Water Treat. 76, 311, 2017.

21. STOSIK M.P., DEPTULA W., DEPTULA-TOKARZ B. Selected immunological and haematological indices in breams (Abramis brama) inhabiting various aquatic ecosystems. Pol. J. Environ. Stud. 11 (3), 273, 2002.

22. BRUCKAJASTRZEBSKA E. The effect of aquatic cadmium and lead pollution on lipid peroxidation and superoxide dismutase activity in freshwater fish. Pol. J. Environ. Stud. 19 (6), 1139, 2010.

23. HONORATO T.B.M., BONI R., DA SILVA P.M., MARQUES-SANTOS L.F. Effects of salinity on the immune system cells of the tropical sea urchin Echinometra lucunter. J. Exp. Mar. Biol. Ecol. 486, 22, 2017.

24. RIVERA-INGRAHAM G.A., NOMMICK A., BLONDEAU-BIDET E., LADURNER P., LIGNOT J.H. Salinity stress from the perspective of the energy-redox axis: Lessons from a marine intertidal flatworm. Redox Biol. 10, 53, 2016.

25. SUREDA A., BOX A., TEJADA S., BLANCO A., CAIXACH J., DEUDERO S. Biochemical responses of Mytilus galloprovincialis as biomarkers of acute environmental pollution caused by the Don Pedro oil spill (Eivissa Island, Spain). Aquat. Toxicol. 101 (3-4), 540, 2011. 
26. AN M.I., CHOI C.Y. Activity of antioxidant enzymes and physiological responses in ark shell, Scapharca broughtonii, exposed to thermal and osmotic stress: effects on hemolymph and biochemical parameters. Comp. Biochem. Physiol. B Biochem. Mol. Biol. 155 (1), 34, 2010.

27. LIU Y., WANG W.N., WANG A.L., WANG J.M., SUN R. Effects of dietary vitamin E supplementation on antioxidant enzyme activities in Litopenaeus vannamei (Boone, 1931) exposed to acute salinity changes. Aquaculture. 265 (1-4), 351, 2007.

28. FREIRE C.A., TOGNI V.G., HERMES-LIMA M. Responses of free radical metabolism to air exposure or salinity stress, in crabs (Callinectes danae and C. ornatus) with different estuarine distributions. Comp. Biochem. Physiol. A Mol. Integr. Physiol. 160 (2), 291, 2011.

29. FANG Z., TIAN X., DONG S., DAI C., WANG G. Analysis of the activity of non-specific immune enzymes of juvenile tongue soles cultured in various salinities. Period. Ocean Univ. China. 44 (5), 46, 2014 [In Chinese].

30. VADDI K., WEI C.I. Effect of ammonium metavanadate on the mouse peritoneal macrophage lysosomal enzymes. J. Toxicol. Environ. Health. 33 (1), 65, 1991.

31. BIRRER S.C., REUSCH T.B., ROTH O. Salinity change impairs pipefish immune defence. Fish Shellfish Immunol. 33 (6), 1238, 2012.

32. WIEGERTJES G.F., STET R.J., PARMENTIER H.K., VAN MUISWINKEL W.B. Immunogenetics of disease resistance in fish: a comparative approach. Dev. Comp. Immunol. 20 (6), 365, 1996.

33. FILICIOTTO F., CECCHINI S., BUSCAINO G., MACCARRONE V., PICCIONE G., FAZIO F. Impact of aquatic acoustic noise on oxidative status and some immune parameters in gilthead sea bream Sparus aurata (Linnaeus, 1758) juveniles. Aquac. Res. 48 (4), 1, 2016. 